\title{
Semantic Feature Analysis Model: Linguistics Approach in Foreign Language Learning Material Development
}

\author{
Mantasiah R. \\ Prof., Universitas Negeri Makassar, Indonesia, mantasiah@unm.ac.id \\ Yusri \\ Universitas Fajar, Indonesia, yusriugm@gmail.com \\ Jufri \\ Universitas Negeri Makassar, Indonesia, jufri@unm.ac.id
}

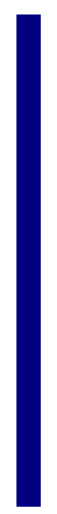

\begin{abstract}
The purpose of this study was to investigate the effect of foreign language learning material development based on the semantic feature analysis model in improving student's learning achievement in English writing and translation subject. This study used classroom action research approach developed by Elliot. Data was collected by using translation test. The total of participants was 45 students who were students Department of English Literature. The data analysis technique used consisted of descriptive statistics and paired sample t-test. This model was implemented during 6 meetings. The result showed that there was a significant increase on the student's learning achievement both in writing class and translation class. It was proved through paired sample t test analysis result which showed that sig. value $(0.00)$ is lower than 0.05 (significance standard). It proved that SFA model can be used as one of effective models in foreign language learning and writing.
\end{abstract}

Keywords: semantic feature analysis, translation, writing, linguistics, EFL

\section{INTRODUCTION}

Various approaches have been proposed for thinking about the English language learning around the world (Mantasiah \& Yusri, 2018; Mantasiah et all., 2018; Yusri et all., 2019; Chen et all., 2019; Burns, 2019; Morady \& Murray, 2019; Flowerdew, 2019). Those studies examined various problems faced by students and offered some strategies which can be implemented to overcome the problems. Problems faced students should be overcome immediately, as the problems can affect negatively to the student's academic achievement. Different problems tend to be overcome by offering the different

Citation: Mantasiah, R., Yusri, \& Jufri. (2020). Semantic Feature Analysis Model: Linguistics Approach in Foreign Language Learning Material Development. International Journal of Instruction, 13(1), 185-196. https://doi.org/10.29333/iji.2020.13112a 
strategies, therefore lecture should be able grasping problems faced students, so they can determine the proper strategy which can be implemented to overcome a problem.

This study focuses to examine student's problem in translation and writing class. Some studies show that students tend to face similar problem both in writing and in translating. The both skills are regarded as the most difficult skills for a learner to master. Generating and organizing ideas using an appropriate choice of vocabulary, sentence, and paragraph organization into a readable text is one of the main difficulties felt by students (Higginbotham \& Reid, 2019). Writing can be defined as an activity or skill of marking coherent words on paper and composing text, while translation is an activity of mediating meaning from a source language into a target language. The ability to choose the correct translation technique is an indispensable skill to translators (Zainudin and Awal, 2012). Intrinsically, there is a similar skill which must be had by students in writing and translation class. Students are supposed to be able choosing appropriate vocabulary.

There are various studies related how to overcome problems faced by lectures and students in translation and writing class (Aryuntini et all., 2018; Lin et all., 2018; Joulin et all., 2018; Ahmed, 2019; Wang \& Liu, 2019). The studies conducted student's problem in translation and writing process and method or strategy which can implemented to solve the problem. One of the problems faced by students in translation class is how to distinguish the words which have similar meaning generally like (get and acquire), (overcome, solve and tackle), (see and look for) and the other similar words. In fact, the problems have influenced negatively to the student's motivation and performance. It was proven by student's translation test result. 45 students were given translation test and the result showed that the majority of students are in the low and very low category, the percentages are $42.22 \%$ and $53.33 \%$ respectively. The result shows that there is no student who can get high score. Generally, the score average of students is 51.66 , and it is in very low category. The result supports previous statement that the majority students have faced problem in distinguishing the words which have similar meaning, especially verbs.

Based on the observation result, some lectures in university still use traditional method. The traditional method is very much oriented towards the 'read and translate' approach as highlighted by Davies (2004). Davies also considers that there should be an alternative approach to the traditional 'read and translate' because translation itself is a complex linguistic process. Therefore, it is important to train students to acquire necessary linguistic skills, as intrinsically linguistics aspect cannot be separated in language teaching. Intrinsically, there are some methods which can be implemented in foreign language learning. Some studies show that teaching materials composed by teachers must be supported by the proper teaching strategies or methods. Therefore, the use of teaching strategy is truly pivotal to be noticed (Mantasiah et all., 2018; Mantasiah \& Yusri, 2018; Ahmadi \& Reza, 2018; Wen, 2018; Rose \& Montakantiwong, 2018)

Based on the problems mentioned previously, students need learning method which can build conceptual knowledge and students are prompted to focus on the relationship between vocabularies. Some studies conducted by Greene \& Coxhead (2015), Esparza 
et all., (2016) Buehl (2017), Vandenbussche (2017) proved that semantic feature analysis which is one of approach in linguistics can be used as one of effective methods in language learning especially in foreign language learning. Semantic feature analysis helps students grasp the "uniqueness" of individual words and aids students in their reading development by increasing their personal and academic vocabulary. By implementing this method, students are hoped to be able gaining insight about the concepts and vocabulary needed in order to comprehend text or topic.

The use of semantic feature analysis in language learning process can improve students' comprehension, vocabulary, and content retention. This strategy helps students to examine related features or concepts and make distinctions among them. By analyzing the completed matrix, students are able to visualize connections, make predictions, and better understand important concepts (Buehl, 2017). Thereore, this method is considered proper to be used an alternative method in translation class. This method also can be implemented by lecture in the whole class, small groups, or individually. Monitoring each student's matrix provides lectures with information about how much the students know about the topic.

By using this model, students will grasp meticulously the use of every vocabulary which has similar meaning, so the students can choose the proper lexicon in translating. This model can also increase student's vocabulary skill, as intrinsically this method uses a matrix to help students discover how one set of things is related to one another. The use of matrix will prosecute students to find other vocabularies which can reflect or describe the main vocabulary.

\section{Semantic Feature Analysis}

One of aspects which must be noticed in language learning is linguistic aspect of the language. It cannot be denied that plenty of lectures have ignored linguistic aspect in teaching foreign language, and in fact it has given rise to negative effects to the students like lack of learning achievement and academic motivation. Semantic feature analysis (SFA) is an approach in linguistics which can be implemented in foreign language learning. SFA is as a strategy which engages students in reading assignments by asking them to relate selected vocabulary to key features of the text. This technique uses a matrix to help students discover how one set of things is related to one another.

Olsen (2016) emphasize that SFA can improve comprehension, vocabulary, and content retention. This strategy helps students to examine related features or concepts and make distinctions among them. By analyzing the completed matrix, it will trigger students to grasp plenty of vocabularies, as when the students completed the matrix, it means that students are able to visualize connections, make predictions, and better understand important concepts. It is supported by Billmeyer (2003) who says that when students use SFA in foreign language learning, it helps them deeper understand the term but also helps their comprehension as well as academic vocabulary. SFA is method designed to teach students how to systematically think about words in terms of their relevant and irrelevant features. The concept will help students grasp the "uniqueness" of individual words and aids students in their reading development by increasing their personal and 
academic vocabulary. Therefore, the method has been shown to be especially effective in improving content area reading vocabulary and comprehension.

Semantic feature analysis works to expand various conceptual categories of schema, through questioning and self-questioning strategies (Ausubel, 1963). There is a strong theory underpinning semantic feature analysis known as schema theory. This theory revolves around the idea that knowledge is organized into units known as schemata. Schemata include information as to how knowledge is used (Rumelhart, 1980). SFA helps students visualize and understand relationships between familiar and less familiar terms while brings the meaning of an unknown term into focus through the generation of analogies and examples. Students are able to integrate their prior knowledge with new information while at the same time building semantically related categories of words and concepts (Olsen, 2016).

To implement this strategy in foreign language learning, there are some steps which must be followed developed based on the theory proposed by Lenski (1999). The steps consist of 1) Select some words which have similar meaning when they are translated in Bahasa Indonesia. 2) Students must find some articles or essays which use the verbs 3 ) Next, assist students in listing the properties or features of the verb across the top row of the chart. 3) Once the matrix is complete, review all the words and properties with the students and have them carefully read the text selection. 4) Ask students to identify which vocabulary words best communicate the essential properties of the topic.

Hall (2006) says that SFA can be implemented with the whole group, small group, or an individual, by either the teacher or a paraprofessional. Hall also proposes the steps to implement this strategy which consist of 1) two or three similar objects are placed in front of the student like pencil, pen or highlighter) 2) A chart listing the three objects across the top, created by teachers, is given to the students. 3) The students are then asked to think of features of objects to list down the side (lead, gray, eraser). 4) After an adequate amount of features are listed down the side. The students compare the two or three objects by adding "“+" or "- "signs in columns to see which objects have the stated features. 5) After this is completed, a definition is then created. This definition is based on the different features that help distinguish each object

\section{METHOD}

This study used classroom action research model by using model developed by Elliot (2007). This approach consists of four phases namely planning, implementation, observation and reflection. Data collection techniques used in this study consisted of observation, interview, and test. The aim of observation was to know responses of students during learning process by using SFA model, and test is used to measure learning achievement of students. The kind of test used was translation test and writing test. In translation test, students were provided an essay which uses Indonesian language, and it must be translated in English version, and in writing test, students should develop an essay (minimum 250 words) based on the topic given. Instrument used in translation and writing test had been validated previously by experts. 
The participants are students of Department of English Literature, University of Fajar, Indonesia who are studying in the first semester. Total of participants is 45 students (28 women and 17 men). This study was conducted in two cycles; each cycle is carried out 3 meetings. Therefore, the total of meetings organized was 6 meetings and every meeting were organized by using SFA model. Based on the student's presence list, it can be seen that all participants attended the meetings fully. The data analysis technique used consisted of descriptive statistics and inferential statistics. Descriptive statistics aims to describe the learning achievement level of students within every cycle. The learning achievement category used was developed by Arikunto (2005). The category can be divided into 5 categories which can be seen clearly on the below table.

Table 1

Categorization of Learning Achievements

\begin{tabular}{lll}
\hline Learning Achievement & Score & Categorization \\
\hline $90 \%-100 \%$ & $90-100$ & Very High \\
$80 \%-89 \%$ & $80-89$ & High \\
$65 \%-79 \%$ & $65-79$ & Middle \\
$55 \%-64 \%$ & $55-64$ & Low \\
$0 \%-54 \%$ & $0-54$ & Very Low \\
\hline
\end{tabular}

Another data analysis technique used was paired sample t-test which was part of inferential statistics. This technique aims to know whether the SFA model implemented in translation class could an increase student learning achievement significantly. Qualitative data collected through observation and interview was analyzed using descriptive qualitative. The data was used as supporting data related student's respond towards semantic feature analysis model.

\section{FINDINGS AND DISCUSSION}

In developing learning material using semantic feature analysis model, the first step done is analyzing the translation result or writing of students by using error analysis approach to find the kind of verbs which have similar meaning which cannot be distinguished by students. After finding the verbs, lecture and students make the semantic features of the verbs. Based on the semantic features, students grasp the differences of the similar verbs. The following verbs are some verbs which cannot be grasped meticulously by the students.

\section{Raze and Demolish}

a. Step 1: Finding the meaning of the verbs

Based on the Oxford learner's dictionaries, 'Raze' means to completely destroy a building, town, etc. so that nothing is left, and demolish means to pull or knock down a building.

b. Step 2: Finding some sentences which use the verbs

1) Raze

- Israel's response has been to raze houses considered guerrilla sanctuaries using the D9 bulldozer 
- $\quad$ The village was razed to the ground.

- The woodland was razed by fire.

2) Demolish

- $\quad$ The old slums are being demolished to make way for a new housing project.

- $\quad$ Tornadoes demolished trailers and blew roofs off houses.

- The army had also begun using bulldozers to demolish some houses being used by Palestinian fighters, soldiers said

c. $\quad$ Step 3: Make the semantic feature differences of the verbs

\begin{tabular}{lcc}
\hline \multicolumn{1}{c}{ Semantic Features } & Raze & Demolish \\
\hline Buildings are not completely destroyed & + & - \\
The object is building or land & + & + \\
\hline
\end{tabular}

According to the feature, it can be concluded that one of feature differences of the both verbs is "raze" means that buildings are not completely destroyed, but "demolish" means that the buildings are completely destroyed.

\section{Say and Tell}

a. Step 1: Finding the meaning of the verbs

Based on the Oxford learner's dictionaries, say means to speak or tell somebody something, using words, and tell means to give information to somebody by speaking or writing.

b. Step 2: Finding some sentences which use the verbs

1) Say

- $\quad$ Anne said, 'I'm tired

- 'There's nothing wrong with him, she said airily.

- It's hard to say what caused the accident.

2) Tell

- He told the story to all his friends.

- I could tell by his face that he was very angry.

- $\quad$ They told stories and jokes while sitting around the camp fire.

c. Step 3: Make the semantic feature differences of the verbs

\begin{tabular}{lll}
\multicolumn{1}{c}{ Semantic Features } & Say & Tell \\
\hline Followed by person as an object & - & + \\
used when we are giving somebody instructions & - & + \\
often used when we are giving somebody's exact words & + & - \\
\hline
\end{tabular}

According to the features, the both verbs can be distinguished clearly. "tell" is always followed by object, and it is used when are giving somebody an instruction, on the contrary, "say" is not followed by object, for example "she says that she will go to the cinema".

\section{Create and Make}

a. Step 1: Finding the meaning of the verbs 
Based on the Oxford learner's dictionaries, make means to create or prepare something by combining materials or putting parts together, and create to make something happen or exist

b. Step 2: Finding some sentences which use the verbs

1) Make

- The stone made a dent in the roof of the car.

- The holes in the cloth were made by moths.

- The cake is made by his parents

2) Create

- The company is trying to create a young energetic image.

- The announcement only succeeded in creating confusion.

- The reorganization has created a lot of bad feeling.

c. Step 3: Make the semantic feature differences of the verbs

\begin{tabular}{lcc}
\multicolumn{1}{c}{ Semantic Features } & Make & Create \\
\hline Often used for physical things & + & - \\
Often used for unphysical things & - & + \\
Combining material & + & - \\
\hline
\end{tabular}

The differences of the both verbs can be understood based on some features, one of them is related object which is followed. "Make" is often used for physical thing, for example "parents make a cake" or "the holes in the cloth were made by moths". On the contrary, "create" is often used for unphysical things.

SFA model was implemented by noticing procedure proposed by Lenski (1999), and Hall (2006). Before starting learning process, learning achievements of students are measured as pre-test data. The previous part, it has been explained that the learning achievements a measured by using translation test. After analyzing pre-test data, the data is categorized into 5 categories based on the Arikunto's categorization.

Table 2

Student's Pre-Test Score Result

\begin{tabular}{llllll}
\hline & & Translation Class & Writing Class \\
\hline Score & Categorization & Frequency & Percentage & Frequency & Percentage \\
\hline $90-100$ & Very High & 0 & $0 \%$ & 0 & 0 \\
$80-89$ & High & 0 & $0 \%$ & 0 & 0 \\
$65-79$ & Moderate & 2 & $4.45 \%$ & 13 & 28,9 \\
$55-64$ & Low & 19 & $42.22 \%$ & 29 & 64,4 \\
$0-54$ & Very Low & 24 & $53.33 \%$ & 3 & 6,7 \\
Total & & 45 & $100 \%$ & 45 & 100 \\
\hline
\end{tabular}

Based on the result of translation pre-test, it can be seen that the majority of students are in the low and very low category, the percentages are $42.22 \%$ and $53.33 \%$ respectively. The result shows that there is no student who can get high score. Generally, the score average of students is 51.66, and it is in very low category. The similar trend is showed by the result of writing pre-test, the majority students are in low category by percentage $64,4 \%$. The score is collected before starting learning process by using SFA model. 
After passing the learning process during 3 meetings, student's learning achievement is re-measured, and the result of test can be seen on the below table.

Table 3

Student's Learning Achievement in the First Cycle

\begin{tabular}{llllll}
\hline & & \multicolumn{2}{l}{ Translation Class } & Writing Class \\
\hline Score & Categorization & Frequency & Percentage & Frequency & Percentage \\
\hline $90-100$ & Very High & 0 & $0 \%$ & 0 & 0 \\
$80-89$ & High & 0 & $0 \%$ & 0 & 0 \\
$65-79$ & Moderate & 18 & $40 \%$ & 39 & 86,7 \\
$55-64$ & Low & 27 & $60 \%$ & 6 & 13,3 \\
$0-54$ & Very Low & 0 & $0 \%$ & 0 & 0 \\
Total & & 45 & 100 & $45 \%$ & 100 \\
\hline
\end{tabular}

According to the table, it can be concluded that the majority of students are in moderate and low category. The percentages are $40 \%$ and $60 \%$ respectively. Generally, the student's score average is 61.88 , and it is in low category. The result shows there is an increase of 10.22 before using SFA model. In writing class, the number of students who are in moderate category increase from 13 to 39 students. The learning process is continued by still using SFA model during 3 meetings, and the student's learning achievement is re-measured after the meetings. The measurement result of student's learning achievement can be seen on the below table.

Table 4

Student's Learning achievement in the Second Cycle (Post-Test)

\begin{tabular}{llllll}
\hline & & \multicolumn{2}{l}{ Translation Class } & Writing Class \\
\hline Score & Categorization & Frequency & Percentage & Frequency & Percentage \\
\hline $90-100$ & Very High & 0 & $0 \%$ & 0 & 0 \\
$80-89$ & High & 8 & $17.78 \%$ & 23 & 51,1 \\
$65-79$ & Moderate & 37 & $82.22 \%$ & 22 & 48,9 \\
$55-64$ & Low & 0 & $0 \%$ & 0 & 0 \\
$0-54$ & Very Low & 0 & $0 \%$ & 0 & 0 \\
Total & & 45 & 100 & $45 \%$ & 100 \\
\hline
\end{tabular}

The table shows that the majority of students are inn moderate and high category. The percentages are $82.22 \%$ and $17.78 \%$ respectively. Generally, the score average is 73.33 , and it is in moderate category. Therefore, it can be seen clearly that there is an increase of 11.44 when it is compared with the student's score in the first cycle. The similar trend is also showed in writing class, students have been in high and moderate category, the percentages were 51,1 and 48,9 respectively. To know whether there is a significant increase on student's learning achievement after passing 6 meetings by using SFA model, the scores are analyzed by using paired sample t test. The analysis result can be seen on the below table. 
Table 5

Paired Samples T-Test of Pre-Test and Post-Test Data in Translation Class

\begin{tabular}{|c|c|c|c|c|c|c|c|}
\hline \multicolumn{5}{|c|}{ Paired Differences } & \multirow[t]{3}{*}{$\mathrm{t}$} & \multirow[t]{3}{*}{$\mathrm{df}$} & \multirow{3}{*}{$\begin{array}{l}\text { Sig. (2- } \\
\text { tailed) }\end{array}$} \\
\hline \multirow[t]{2}{*}{ Mean } & \multirow[t]{2}{*}{$\begin{array}{l}\text { Std. } \\
\text { Deviation }\end{array}$} & \multirow[t]{2}{*}{$\begin{array}{l}\text { Std. Error } \\
\text { Mean }\end{array}$} & $\begin{array}{l}95 \% \mathrm{C} \\
\text { the Dif }\end{array}$ & $\begin{array}{l}\text { nce Interval of } \\
\text { n }\end{array}$ & & & \\
\hline & & & Lower & Upper & & & \\
\hline 21,667 & 5,539 &, 826 & 20,003 & 23,331 & 26,240 & 44 & ,000 \\
\hline
\end{tabular}

The table shows that there is an increase of 21.667 after passing 4 meetings. Based on the table, sig. Value (0.00) is lower than 0.05 (significance standard). It means that there is a significant increase on the student's learning achievement by using SFA model. Moreover, the analysis result shows that $\mathrm{t}$-table is 26.240 and $\mathrm{t}$-count is 1.680 . It proves that the difference of pre-test score and the student's score in second cycle is significant. Therefore, SFA Model is proved as effective model in increasing student's learning achievement on English foreign language learning especially in translation class. The similar result can be seen on the writing result.

Table 5

Paired Samples T-Test of Pre-Test and Post-Test Data in Writing Class

\begin{tabular}{|c|c|c|c|c|c|c|c|}
\hline \multicolumn{5}{|c|}{ Paired Differences } & $\mathrm{t}$ & $\mathrm{df}$ & Sig. (2-tailed) \\
\hline \multirow[t]{2}{*}{ Mean } & $\begin{array}{l}\text { Std. } \\
\text { Deviation }\end{array}$ & $\begin{array}{l}\text { Std. Error } \\
\text { Mean }\end{array}$ & $\begin{array}{l}95 \% \mathrm{C} \\
\text { the Dif }\end{array}$ & ce Interval of & & & \\
\hline & & & Lower & Upper & & & \\
\hline 16,667 & 5,000 & ,745 & 15,165 & 18,169 & 22,361 & 44 & ,000 \\
\hline
\end{tabular}

The table shows that there is an increase of 16.667 after passing 4 meetings. The previous table shows that before starting the learning process, most of students were in low category, and after passing 6 meetings, the majority of students were in high category. Another information that significant value of the table $(0.00)$ is lower than 0.05 (significance standard). It means that there is a significant increase on the student's learning achievement by using SFA model. Moreover, the analysis result shows that ttable is 22.361 and t-count is 1.680 . It proves that the difference of pre-test score and the student's score in second cycle is significant.

Students also were interviewed to get their responses related the use of SFA model in foreign language teaching. Most of students say that the model was composed based on the student's need. One of aspects which must be noticed in designing teaching material and the kinds of approach implemented in the learning process, one of them is understanding student's need and ability (Nation \& Macalister, 2009). Lee (2013) says that textbooks or course books provided by teachers must be composed based on student's need.

SFA model is composed based on the student's need, as before starting the learning process, student's temporary test result in writing and translation class is analyzed by using error analysis approach. The result of the approach shows the kinds of verbs which cannot be distinguished by students. The kinds of mistake or error made by students would be emphasized indepthly in the learning process. One of the case studies, when students were instructed to translate "dengan belajar, siswa dapat memperoleh 
ilmu pengetahuan". Some students wrote "By learning, students can get knowledge”. Intrinsically, the proper lexicon which can be used to translate "memperoleh ilmu pengetahuan" is "acquire knowledge". After knowing that students cannot distinguish 'get' and 'acquire', lecture would support students to make SFA model by using the both verbs.

Based on the result, it can be concluded that semantic feature analysis model also can be used as one of strategies in composing learning material. Lectures must identify plenty of verbs which cannot be distinguished by students, and the lectures make SFA of the verbs and it is provided in teaching material forms, as intrinsically, teaching materials are regarded as a key factor in most language programs (Richards, 2014). The result of this study supports previous studies like Fisher and Frey (2004), Buehl (2017) which show that the use of semantic feature analysis as a learning method can increase student's ability in understanding lexicon. After implementing this model, students can grasp meticulously the similar lexicons and distinguish the lexicons. The finding is similar with theory proposed by Billmeyer (2003) who says that SFA helps students deeper understand similar terms and it can increase the student's vocabulary skill indirectly.

\section{CONCLUSION}

Semantic Feature Analysis (SFA) model is one of foreign language learning models by noticing linguistics aspect of the language. Linguistics aspect noticed is semantics aspect. After passing 6 meetings by using SFA model, it can be concluded that there is a significant increase on the student's learning achievement especially in writing and translation class. It was proved through paired sample t test analysis result which showed that sig. value (0.00) is lower than 0.05 (significance standard). SFA is not only used as strategy or method in the foreign language learning, but also can be used as one of strategies in composing teaching material used in learning process.

\section{REFERENCES}

Ahmadi, D., \& Reza, M. (2018). The use of technology in English language learning: A literature review. International Journal of Research in English Education, 3(2), 115125. doi: 10.29252/ijree.3.2.115.

Ahmed, A. M. (2019). Effects and students' perspectives of blended learning on English/Arabic translation. Arab Journal of Applied Linguistics, 4(1), 50-80.

Arikunto. S. (2005). Dasar - dasar evaluasi pendidikan. Bumi Aksara. Jakarta.

Aryuntini, N., Astuti, I., \& Yuliana, Y. (2018). Development of learning media based on video scribe to improve writing skill for descriptive text of English language study. Journal of Education, Teaching and Learning, 3(2), 187-194. doi: 10.26737/jetl.v3i2.746.

Ausubel, D. P. (1963). The psychology of meaningful verbal learning; an introduction to school learning. New York, NY: Grune \& Stratton. 
Billmeyer, R. (2010). Strategies to engage the mind of the learner: Building strategic learners. Moorabbin, Vic.: Hawker Brownlow Education.

Buehl, D. (2017). Classroom strategies for interactive learning. Stenhouse.

Burns, A. (2019). Concepts for teaching speaking in the English language classroom. LEARN Journal: Language Education and Acquisition Research Network, 12(1), 1-11.

Chen, T., Auidi, D., Gouioa, R., Chapron, B., Chen, C. Y. J., \& Wee, H. (2019). New math teaching methodologies for English language e-learner's students. Journal of $e$ Learning and Knowledge Society, 15(1), 83-94. doi: 10.20368/1971-8829/1564.

Davies, M. G. (2004). Multiple voices in the translation classroom: Activities, tasks and projects. Amsterdam and Philadelphia: John Benjamins Publishing.

Elliott, J. (2007). Reflecting where the action is: The selected writings of John Elliott, world library of educationalists. New York: Routledge.

Esparza, G. G., Díaz, A. P., Canul-Reich, J., De-Luna, C. A., \& Ponce, J. (2016). Proposal of a sentiment analysis model in tweets for improvement of the teachinglearning process in the classroom using a corpus of subjectivity. International Journal of Combinatorial Optimization Problems and Informatics, 7(2), 22-34.

Fisher, D., \& Frey, N. (Eds.). (2004). Improving adolescent literacy: Strategies at work. Upper Saddle River, NJ: Pearson.

Flowerdew, J. (2019). The linguistic disadvantage of scholars who write in English as an additional language: Myth or reality. Language Teaching, 52(2), 249-260. doi: $10.1017 / \mathrm{S} 0261444819000041$.

Greene, J. W., \& Coxhead, A. (2015). Academic vocabulary for middle school students. Baltimore, MD: Paul H. Brookes.

Hall, S. L. (2006). I've DIBEL'd, Now what? Designing interventions with DIBELS data. Sopris West.

Higginbotham, G., \& Reid, J. (2019). The lexical sophistication of second language learners' academic essays. Journal of English for Academic Purposes, 37, 127-140. doi: 10.1016/j.jeap.2018.12.002.

Joulin, A., Bojanowski, P., Mikolov, T., Jégou, H., \& Grave, E. (2018). Loss in translation: Learning bilingual word mapping with a retrieval criterion. arXiv, 1804.07745 .

Lee, Y. (2003). A package for an English paragraph: An evaluation of the coursebook used in two EFL writing courses. English Teaching, 58(3), 165-188.

Lenski, S. D., Wham, M. A., \& Johns, J. L. (1999). Reading \& learning strategies for middle \& high school students. Dubuque, IA: Kendall/Hunt.

Lin, C. J., Hwang, G. J., Fu, Q. K., \& Chen, J. F. (2018). A flipped contextual gamebased learning approach to enhancing EFL students' English business writing 
performance and reflective behaviors. Journal of Educational Technology \& Society, 21(3), 117-131.

Mantasiah, R, Yusri. Y., \& Jufri J. (2018). The development of grammar teaching material using error and contrastive analysis (a linguistic approach in foreign language teaching). TESOL International Journal, 13(3), 2-11.

Mantasiah, R. (2018). Pay it forward model in foreign language learning to increase student's self-efficacy and academic motivation. Journal of Physics: Conference Series 1028(1), 012178. doi: 10.1088/1742-6596/1028/1/012178.

Morady, M., \& Murray, N. (2019). English language teaching in Iran: A case of shifting sands, ambiguity, and incoherent policy and practice. International Journal of Society, Culture \& Language, 7(1), 96-105.

Nation, I. S., \& Macalister, J. (2009). Language curriculum design. New York \& London: Routledge.

Olsen, M. B. (2016). A semantic and pragmatic model of lexical and grammatical aspect. New York: Routledge.

Richards, J. C., \& Rodgers, T. S. (2014). Approaches and methods in language teaching. Cambridge, UK: Cambridge university press.

Rose, H., \& Montakantiwong, A. (2018). A tale of two teachers: A duo ethnography of the realistic and idealistic successes and failures of teaching English as an international language. RELC Journal, 49(1), 88-101.

Rumelhart, D. E. (1980). Schemata: The building blocks of cognition. In R. J. Spiro, B. C. Bruce, \& W. F. Brewer (Eds.), Theoretical issues in reading comprehension: Perspectives from cognitive psychology, linguistics, artificial intelligence, and education (pp. 33-58). Hillsdale, NJ: Lawrence Erlbaum.

Vandenbussche, P. Y., Atemezing, G. A., Poveda-Villalón, M., \& Vatant, B. (2017). Linked open vocabularies (LOV): A gateway to reusable semantic vocabularies on the web. Semantic Web, 8(3), 437-452

Wang, X., \& Liu, C. (2019, February). Research on the cultivation of English translation ability of undergraduates in smart learning environment. In International Conference on Application of Intelligent Systems in Multi-modal Information Analytics (pp. 10231028). Springer, Cham.

Wen, Q. (2018). The production-oriented approach to teaching university students English in China. Language Teaching, 51(4), 526-540.

Yusri, Y., Romadloni, A., \& Mantasiah, R. Intercultural approach in foreign language learning to improve students' motivation. Asian EFL Journal, 98, 61-73.

Zainudin, I. S., \& Awal, N. M. (2012). Translation techniques: Problems and solutions. Procedia-Social and Behavioral Sciences, 59, 328-334. 